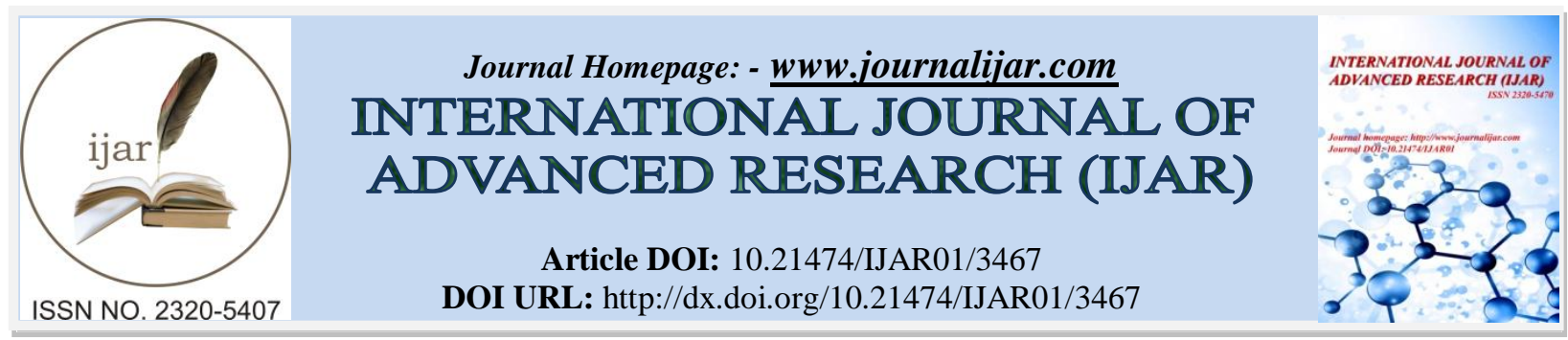

RESEARCH ARTICLE

\title{
A SYSTEMATIC REVIEW STUDYING THE EFFECT OF DIFFERENT FRAMEWORK MATERIALS ON THE RETENTION OF IMPLANT TELESCOPIC OVERDENTURES.
}

\author{
Mohamed Marwan Sadik Rahhal and Ahmed Emad Fayyad.
}

\section{Manuscript Info}

.........................

Manuscript History

Received: 28 December 2016

Final Accepted: 17 January 2017

Published: February 2017

Key words:-

Dental implants, Telescopic overdenture,

Retention, Implant supported

overdenture, Prosthesis retention.

\begin{abstract}
The aim of this study is to systematically evaluate and compare between implant-supported telescopic retained overdentures reinforced by framework made of different materials in terms of retention. Search was made in 3 databases including PubMed, Ebscohost and Google scholar, title and abstract were screened to select studies related to telescopic overdenture and measuring its retention. Articles which did not follow the inclusion criteria were excluded. Included papers were then read carefully for a second stage filter, this was followed by manual searching of bibliography of selected articles. The search resulted in 15 included papers. These studies aimed to study the impact of the manufacturing technique and the recently introduced variable materials of the telescopic crowns on the retentive forces.
\end{abstract}

Copy Right, IJAR, 2017,. All rights reserved.

\section{Introduction:-}

Patients with conventional denture mostly complain from poor denture retention and stability especially in the mandibular denture. Problems with complete denture prostheses arise from the inability to function with the mandibular prostheses. Reasons that affect successful use of a complete denture in the mandible include; the mobility of the floor of the mouth, alveolar ridge lined with thin mucosa, decreased support area and the mobility of the mandible. ${ }^{[1]}$

Implant-supported overdentures are an accepted and reliable treatment for edentulous jaws. Clinical studies have revealed high implant and prosthesis survival rates over observational periods of up to 10 years and a high level of patient satisfaction, as well as an improvement in quality of life compared to conventional dentures. ${ }^{[2]}$

Attachments used in conjunction with implants were found to enhance the retention, stability and support of overdentures. The commonly used attachment systems connecting overdentures and implants have included bars of different designs, studs and telescopic systems. The concept of implant retained telescopic overdentures has been shown to be effective in prosthesis stabilization with regard to horizontal forces in cases of advanced atrophy of the alveolar crest.

The focus of attention in implant dentistry is shifting from "survival" to "quality of survival." Highly aesthetic restorations are becoming important criteria for the definition of success, thus non-metallic materials are now available, which imply the use of new technology and all with the advantages of superior esthetics and reduced potential for allergic reactions. ${ }^{[3]}$ 
Our arising question will be in completely edentulous patient, will the material of telescopic implants overdenture have an impact on the retention?

\section{Materials and Methods:-}

\section{Search Strategy:-}

An Electronic Search of the literature was performed on PubMed,Ebscohost and Google scholar, using the following search terms :

1. Dental implants (Dental implants, Implants, Osseointegrated dental implants, Toothless overdenture, Implant supported overdenture, Osseointegrated implants)

2. Telescopic overdenture( Konus crown, Conus crown, Dental telescopic retainer, Dental telescope, Denture retention, Prosthesis retention, Denture prosthesis retention)

3. Retention (Retention denture, Denture dislodgment, Denture retentivity, Dental telescopic retainer, Denture retention, Prosthesis retention, Dental prosthesis retention, Dental prosthesis displacement)

4. Hand search was done on the bibliography of the included papers. Last hand search was performed on the 19th of February - 2017.

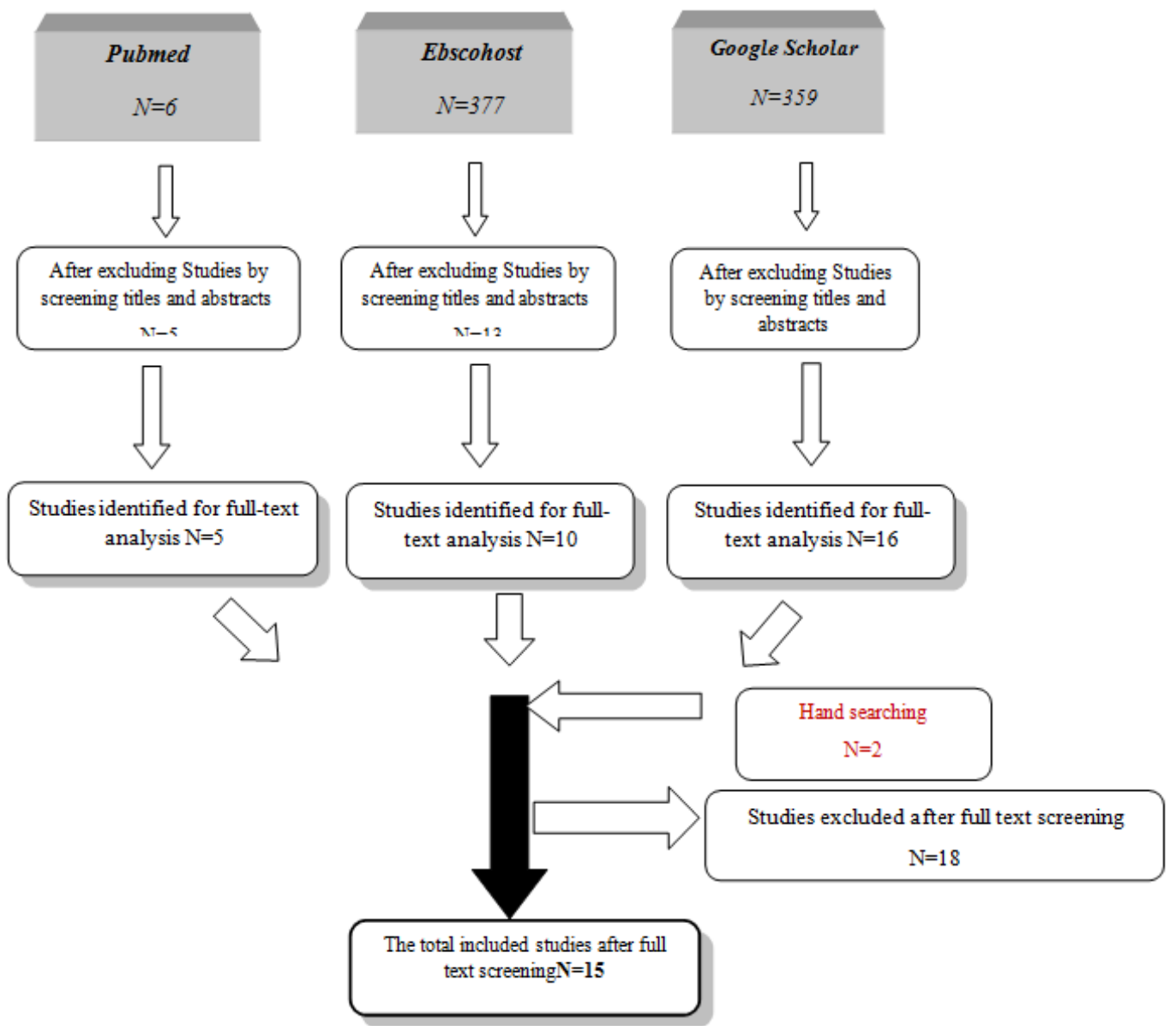

\section{Selection criteria:-}

Inclusion criteria:-

1. Completely and partially edentulous patient

2. Mandibular and maxillary telescopic overdenture.

3. In vivo and in vitro studies. 


\section{Exclusion criteria:-}

a. Medically compromised patient.

b. Studies on animals.

\section{Study Selection:-}

Retrieved titles were all screened, and all papers that met the inclusion criteria were selected. Abstracts of all headings chosen were screened and obtained for inclusion criteria. After abstracts were screened, full text studies were retrieved for the selected papers. In case both the heading and the abstract of an article wasn't enough to obtain data needed to make a decision regarding inclusion criteria, full texts were retrieved. Full text papers meeting inclusion criteria were screened upon their methodology and results. Two reviewers performed the screening procedure.

\section{Results:-}

A total of 742 titles were identified by the electronic search. After initial titles and abstracts screening , 701 irrelevant articles were excluded and a total of 41 articles were selected for full-text screening, 2 additional articles were found through hand searching ${ }^{[4,5]}$. After full text screening, 15 articles ${ }^{[4-18]}$ were included in the present analysis.

The 15 articles included in this study were published in a period ranging from 2003-2016 except one article at $1996^{[8]}$. They differed widely with respect to methodology, study designs and outcomes. So the possibility of attempting a meta-analysis was eliminated.

The demographic data of the included articles were presented in (Table 1). The included studies showed the variability in the manufacturing method of the telescoping crowns (CAD/CAM milling, casting, electroforming, electroplating) as well as the difference of the materials of the primary and the secondary copings. The variable materials used in the following studies were zirconium, gold, PEEK (polyetheretherketone), titanium and cobalt chromium interchangeably. Surface roughness and the degree of taper were also revealed (Table 2).

The specifications of the copings beside the variation in the materials used between the primary and the secondary copings had an influence on the retentive forces during the follow up period (Table 3).

Table 1:-Table of demographic findings.

\begin{tabular}{|c|c|c|c|c|}
\hline Studies & Age range & Sex & Settings & $\begin{array}{l}\text { Mandible } \\
\text { or Maxilla }\end{array}$ \\
\hline $\begin{array}{l}\text { Grossman AC. Et al. } 2007 \\
\text { Treatment with Double } \\
\text { Crown-Retained } \\
\text { Removable PartialDentures } \\
\text { and Oral Health-Related } \\
\text { Quality of Life in Middleand } \\
\text { High-Aged Patients }\end{array}$ & $\begin{array}{l}\text { Mean age } \\
65\end{array}$ & $\begin{array}{l}63.3 \% \mathrm{~m} \\
37.7 \% \mathrm{f}\end{array}$ & $\begin{array}{l}\text { Prosthodontic department } \\
\text { of the university of } \\
\text { Heidelberg, Germany }\end{array}$ & $\begin{array}{l}\text { Mandible } \\
\text { and maxilla }\end{array}$ \\
\hline $\begin{array}{l}\text { Uludag B. et al. } 2008 \\
\text { Fabrication of Zirconium } \\
\text { Primary Copings to Provide } \\
\text { retention for a Mandibular } \\
\text { Telescopic Overdenture }\end{array}$ & 58 & female & $\begin{array}{lr}\text { Department } & \text { of } \\
\text { prosthodontics } & \text { Ankara } \\
\text { university } & \end{array}$ & Mandible \\
\hline $\begin{array}{l}\text { Besimo C et al. } 1996 \\
\text { Retention force changes in } \\
\text { implant-supported } \\
\text { titaniumtelescope crowns } \\
\text { over long-term use in vitro }\end{array}$ & & & & \\
\hline $\begin{array}{l}\text { Bayer } \mathrm{S} \text { et al. } 2012 \\
\text { Telescopic crowns: Extra- } \\
\text { oral and intraoral retention } \\
\text { force measurement-In vitro } \\
\text {, in vivo correlation }\end{array}$ & Meanage59 & $\begin{array}{l}23 \text { partially edentulous } \\
\text { patients }\end{array}$ & $\begin{array}{l}\text { University of Bonn, } \\
\text { Germany }\end{array}$ & $\begin{array}{l}15 \text { maxillary } \\
\text { and } 10 \\
\text { mandibular }\end{array}$ \\
\hline
\end{tabular}




\begin{tabular}{|c|c|c|c|c|}
\hline $\begin{array}{l}\text { Singh K \& GuptaN } 2012 \\
\text { Telescopic Denture- A } \\
\text { treatment modality for } \\
\text { minimizing the conventional } \\
\text { removable complete denture } \\
\text { problems }\end{array}$ & $\begin{array}{l}52 \text { years } \\
\text { old }\end{array}$ & male & private dental center & $\begin{array}{l}\text { maxillary } \\
\text { telescopic } \\
\text { denture } \\
\text { mandibular } \\
\text { bar } \\
\text { supported } \\
\text { overdenture }\end{array}$ \\
\hline $\begin{array}{l}\text { Kwon H B \& Lee SH } 2006 \\
\text { The Comparison Of Initial } \\
\text { Retentive Force in Different } \\
\text { Double Crown Systems }\end{array}$ & & & N/A & N/A \\
\hline $\begin{array}{l}\text { Jin Yi Y \& Park JC } 2003 \\
\text { Cause Of Technical Failures } \\
\text { Of Conical } \\
\text { Crown-Retained } \quad \text { Denture } \\
\text { (CCRD) }\end{array}$ & $\begin{array}{l}43-66 \\
\text { years old }\end{array}$ & Males & $\begin{array}{l}\text { Department } \\
\text { prosthodontics of and } \\
\text { research institute of oral } \\
\text { science, College of } \\
\text { dentistry, } \\
\text { Kangnung } \\
\text { University }\end{array}$ & Mandible \\
\hline $\begin{array}{l}\text { Sakai Y et al. } 2011 \\
\text { Effects of surface roughness } \\
\text { and tapered angle of cone } \\
\text { crown telescopic system on } \\
\text { retentive force }\end{array}$ & N/A & $\begin{array}{l}3 \text { models were } \\
\text { prepared:- } \\
1^{\text {st group :- } 2 \text { of them }} \\
\text { with same surface } \\
\text { roughness (smooth) and } \\
\text { taper }(4,5 \text { degrees) } \\
2^{\text {nd group:- }} \text { with } \\
\text { different roughness } \\
\text { (rough) than the } 1^{\text {st }} \\
\text { group and taper } 6 \\
\text { degrees made of two } \\
\text { different cone crown :- } \\
\text { a)prefabricated } \\
\text { b)CAD/CAM miled }\end{array}$ & N/A & N/A \\
\hline $\begin{array}{l}\text { Mansour S etal. } 2016 \\
\text { All-ceramic one-piece } \\
\text { telescopic abutments for } \\
\text { implant-supported } \\
\text { overdentures }\end{array}$ & N/A & females & $\begin{array}{l}\text { Martin-Luther university } \\
\text { Hollo-Weitenbergcentre } \\
\text { for Dentistry and Oral } \\
\text { Medicine/ Department of } \\
\text { prosthodontics }\end{array}$ & $\begin{array}{l}1^{\text {st }} \text { case: } \\
\text { Edentulous } \\
\text { maxilla } \\
\text { Partially } \\
\text { edentulous } \\
\text { mandible } \\
2^{\text {nd }} \text { case: } \\
\text { Edentulous } \\
\text { maxilla } \\
\text { Partially } \\
\text { edentulous } \\
\text { mandible }\end{array}$ \\
\hline $\begin{array}{l}\text { Gurbulak AG et al. } 2012 \\
\text { Evaluation of the Retention } \\
\text { Force of Double Conical } \\
\text { CrownsUsed with a } \\
\text { Combination wion } \\
\text { Galvanoforming } \\
\text { CastingFabrication } \\
\text { Technique }\end{array}$ & & & & \\
\hline
\end{tabular}




\begin{tabular}{|c|c|c|c|c|}
\hline $\begin{array}{l}\text { Riera JJG et al. } 2006 \\
\text { Alternative Designs in } \\
\text { Implant-Retained Maxillary } \\
\text { Overdentures: The } \\
\text { Telescopic Approach }\end{array}$ & 60-year-old & male & N/A & $\begin{array}{l}\text {-restore the } \\
\text { maxilla with } \\
\text { an implant- } \\
\text { supported } \\
\text { overdenture } \\
\text { se using } \\
\text { seven } \\
\text { implants } \\
\text {-The } \\
\text { mandibular } \\
\text { archwould } \\
\text { have an } \\
\text { implant- } \\
\text { supported } \\
\text { fixed } \\
\text { ceramometal } \\
\text { restoration } \\
\text { (8 implants } \\
\text { in the } \\
\text { mandible) }\end{array}$ \\
\hline $\begin{array}{l}\text { Bayer } S \text { et al. } 2010 \\
\text { Retention } \\
\text { measurement of telescopic } \\
\text { crowns }\end{array}$ & 43 patient & N/A & $\begin{array}{l}\text { Department of } \\
\text { Prosthodontics,Preclinical } \\
\text { Education and Dental } \\
\text { Materials Science } \\
\end{array}$ & N/A \\
\hline $\begin{array}{l}\text { Stock V et al. } 2016 \\
\text { PEEK Primary Crowns } \\
\text { with Cobalt-Chromium, } \\
\text { Zirconia and Galvanic } \\
\text { Secondary Crowns with } \\
\text { Different } \\
\text { Comparison of Retention } \\
\text { Forces }\end{array}$ & & $\begin{array}{l}90 \text { double crowns } \\
\text { (i) } \quad 30 \text { CoCr-crowns } \\
\text { milled } \\
\text { (ii) } 30 \quad \mathrm{ZrO} \text {-crowns } \\
\text { milled from Ceramill ZI } \\
\text { (iii) } 30 \quad \text { GAL-crowns } \\
\text { made r using } \\
\text { electroforming }\end{array}$ & N/A & \\
\hline $\begin{array}{l}\text { Turp I et al. } 2014 \\
\text { Retention and } \\
\text { changes of zurconia primary } \\
\text { crownswith } \\
\text { crowns of } \\
\text { materials }\end{array}$ & & $\begin{array}{l}\text { 12groups, each } \\
\text { containing six samples, } \\
\text { consisting of: } \\
\text { (i) gold alloy 1ry } \\
\text { crownelectroformedgold } \\
\text { 2ry crowns } \\
\text { (ii) zirconia 1rycrown- } \\
\text { electroformed gold 2ry } \\
\text { crowns } \\
\text { (iii)zirconia 1ry crown- } \\
\text { casted non-precious } \\
\text { alloy 2ry crowns conus } \\
\text { angles of } 0^{\circ}, 2^{\circ}, 4^{\circ} \text {, and } \\
6^{\circ} \text {. }\end{array}$ & & \\
\hline $\begin{array}{l}\text { Pietruski J K et al. } 2013 \\
\text { Retention force assessment } \\
\text { in conical crownsin different } \\
\text { material combinations }\end{array}$ & & $\begin{array}{l}12 \text { crown pairs of two } \\
\text { different connections : } \\
\text { (i)gold casting } \\
\text { alloy/gold casting alloy } \\
\text { (ii) gold casting } \\
\text { alloy/gold } \\
\text { electroforming alloy. } \\
\text { with the cone angles of } \\
2^{\circ}, 4^{\circ} \text { and } 6^{\circ} \text {. }\end{array}$ & & \\
\hline
\end{tabular}


Tables 2 \& 3:- showing Methodology and Results

\begin{tabular}{|c|c|c|}
\hline STUDIES & Methododology & ASESSEMENT \\
\hline Grossman AC et al. & $\begin{array}{l}2 \text { groups: } \\
\begin{array}{l}\text { 1- } 2 \text { ry crowns made by galvanoforming technique } \\
\text { with } 0 \text { degree 1ry crown } \\
\text { 2- } 1 \text { ry crown with } 6 \text { degrees }\end{array}\end{array}$ & $\begin{array}{l}\text { He measures retention } \\
\text { which has an impact on } \\
\text { the Oral Health Related } \\
\text { Quality of } r \text { Life } \\
\text { (OHRQoL) with oral } \\
\text { health impact profile } \\
\text { (OHIP) }\end{array}$ \\
\hline Uludag B et al. & $\begin{array}{l}\text { A mandibular telescopic overdenture retained by } \\
\text { electroformed 2ry copings with zirconia 1ry coping }\end{array}$ & \\
\hline Besimo C et al. & $\begin{array}{l}2 \text { groups } \\
\text { The experiment is made on } 40 \text { specimens which are divided } \\
\text { into } 2 \text { groups ( } 20 \text { each) in the first group the primary coping } \\
\text { was made from gold while the second group made of pure } \\
\text { titanium. } \\
\text { Each twenty were divided into two equal groups. In the first } \\
\text { group the cone angle was } 5.5 \text { degrees while the second } \\
\text { group was } 6.5 \text { degrees. Five of the secondary copings ware } \\
\text { fabricated from Cr-Co and the other five from gold alloys. } \\
\text { The secondary coping was placed on the inner coping with a } \\
\text { force of } 20 \mathrm{~N} \text { which correspond to the average masticatory } \\
\text { force. } \\
\text { Insertion separation cycled was } 10000 \text {. Saliva substitute was } \\
\text { used. }\end{array}$ & Retention \\
\hline Bayer S et al 2011 & $\begin{array}{l}\text { In vitro part: he used artificial saliva } \\
\text { In vivo measurements were performed 4-6 weeks after the } \\
\text { denture insertion. } \\
\text { The attachment was cast into type IV gold alloy. } \\
\text { The specifications of the secondary coping: } 0.4-0.5 \mathrm{~mm} \text { - } \\
\text { sand blasted-further finishing of the inner surface was } \\
\text { performed using burnishers with different levels of } \\
\text { roughness. } \\
\text { Tapering was 1-2degrees } \\
\text { Before measurement the telescopic crowns were cleaned of } \\
\text { adherent food or plaque. } \\
\text { The point of measurement should not be located further than } \\
\text { the distal surface of the second premolar. The retentive } \\
\text { force was measured for the inicial separation of the } \\
\text { telescopic crowns approximately from the first } 0.1 \text { mm of } \\
\text { separation }\end{array}$ & Retention \\
\hline Singh K \& Gupta N & $\begin{array}{l}\text { Maxillary right and left canine, mandibular right and left } \\
\text { canine and mandibular right premolar- } \\
\text {-Intentional RCT then long abutments were prepared 2-5 } \\
\text { degrees, while short abutments parallel. } \\
\text {-secondary coping with metalprojections (retention beads) } \\
\text { for mechanical interlocking to denture surface. }\end{array}$ & \\
\hline Kwon H B \& Lee SH & $\begin{array}{l}10 \text { dies for double crowns were fabricated. Two kinds of } \\
\text { inner crown were fabricated. Five inner crowns were } \\
\text { fabricated for hybrid crowns and } 5 \text { others were made for } \\
\text { conus crowns. } \\
\text { Five inner crowns for hybrid crowns had a } 3 \mathrm{~mm} \text { parallel } \\
\text { axial wall gingivally and a } 3 \mathrm{~mm} \text { inclined plane, which } \\
\text { conformed to the outer contour of prepared teeth occlusally. } \\
\text { Five inner crowns for conus crowns with heights of } 6 \mathrm{~mm} \\
\text { and }\end{array}$ & \\
\hline
\end{tabular}




\begin{tabular}{|c|c|c|}
\hline & $\begin{array}{l}\text { a cone angle of } 2 \text { degrees were fabricated. } \\
\text { An inner crown was placed into the holding apparatus of a } \\
\text { universal testing machine, and the outer crown was placed } \\
\text { onto the inner crown and connected } \\
\text { to the holding apparatus of a universal testing machine. } \\
\text { Compressive force was applied to the inner-outer crown } \\
\text { assembly at a cross head speed of } 100 \mathrm{~cm} / \mathrm{min} \text { until full } \\
\text { seating was achieved, and then tensile strength was } \\
\text { measured at the same cross head speed. For all } \\
\text { measurements, artificial saliva was introduced between the } \\
\text { outer and inner crowns. }\end{array}$ & \\
\hline Jin Yi Y \& Park C & $\begin{array}{l}\mathbf{1}^{\text {st }} \text { group:- When inner copings were luted to the abutments, } \\
\text { it was found that excessive force was required for insertion } \\
\text { and removal of the denture. The patient complained of the } \\
\text { pain and difficulties of insertion and removal of a denture. } \\
\mathbf{2}^{\text {nd }} \text { group:- internal gaps were found both between the outer } \\
\text { and inner crown ofright first premolar, and between the } \\
\text { residual ridge and free-end denture base . Even after relining } \\
\text { procedure, fit and retentive force of retainers were still } \\
\text { insufficient. }\end{array}$ & $\begin{array}{lr}\text { Problems } & \text { were } \\
\text { experienced } & \text { with } \\
\text { overdenture } & \text { especially } \\
\text { those related to retention. }\end{array}$ \\
\hline Sakai Y et al. & $\begin{array}{l}\text { - The average surface roughnesses of the smooth and rough } \\
\text { surfaces of the inner crown were } 0.1 \text { and } 1.5 \mu \mathrm{m} \text {, } \\
\text { respectively; those of the outer crown were } 0.1 \text { and } 1.2 \mu \mathrm{m} \text {, } \\
\text { respectively. The } 4 \text { and } 5^{\circ} \text { inner and outer crowns were } \\
\text { prepared only with a smooth surface. } \\
\text { - During measuring the retentive force the piston of the test } \\
\text { machine applied a } 100-\mathrm{N} \text { load on the test assembly, moved } \\
2.5 \mathrm{~mm} \text { upward to separate the outer crown at a separation } \\
\text { speed of } 50 \mathrm{~mm} / \mathrm{min} \text {, and then returned downward to insert } \\
\text { the outer crown until } 100-\mathrm{N} \text { load applied. } \\
\text { - One thousand consecutive cycles of separation and } \\
\text { insertion were performed at } 10 \text { cycles/minute. This test set- } \\
\text { up permitted separation to be performed and evaluated in } \\
\text { the axial direction only. }\end{array}$ & $\begin{array}{l}\text { This study evaluated the } \\
\text { effect of surface roughness } \\
\text { and tapered angle of cone } \\
\text { crowns on retentive force. }\end{array}$ \\
\hline Mansour S et al. & $\begin{array}{l}1^{\text {st }} \text { case:- } \\
6 \text { implants in maxilla } \\
3 \text { implants in mandible to complete unilateral arch } \\
\text {-One piece abutment (highly electroplated) and framework } \\
\text { were milled into zirconium by a special CAD/CAM system } \\
\text { then cemented as a 1ry coping. } \\
2^{\text {nd }} \text { case:- } \\
\text {-combined teeth and implant } \\
\text {-coping are milled with CAD/CAM then cemented }\end{array}$ & $\begin{array}{l}\text { The aim of this study was } \\
\text { to present the application } \\
\text { of all ceramic CAD/CAM } \\
\text { milled zirconia one piece } \\
\text { implant telescopic } \\
\text { abutments in complex } \\
\text { clinical situations. }\end{array}$ \\
\hline Gurbulak AG et al. & $\begin{array}{l}\text { The maxillary right second premolar was prepared using } \\
\text { commercially available models. } \\
\text {-A tapered conus angle of } 3 \circ \text { and a chamfer width of } 1 \mathrm{~mm} \\
\text { were created using a parallelometer for the master metal die. } \\
\text { - } 10 \text { models were used for each group. } \\
\text { - inner surfaces of the 1ry crowns and outer surfaces of the } \\
\text { 2ry crowns were sandblasted with } 110 \mu \mathrm{m} \text { aluminum oxide } \\
\text { particles for the evaluation of the initial retention force and } \\
\text { weight. To simulate wear, specimens were inserted in } \\
\text { specially designed wear equipment (The crowns were } \\
\text { inserted and separated } 3285 \text { times in a horizontal direction, }\end{array}$ & $\begin{array}{lr}\text { To measure an in vitro } \\
\text { retention force } & \text { of } \\
\text { doubleconical } & \text { crowns } \\
\text { fabricated using } & \text { primary } \\
\text { galvanoforming } & \text { and } \\
\text { secondary } & \\
\text { castingtechniques } & \text { and } \\
\text { those fabricated } & \text { using } \\
\text { primary casting } & \text { and } \\
\text { secondary galvanoforming } \\
\text { techniques } & \text { under } \\
\text { simulated } & \text { clinical }\end{array}$ \\
\hline
\end{tabular}




\begin{tabular}{|c|c|c|}
\hline & $\begin{array}{l}\text { to simulate a patient's removal and replacement of the } \\
\text { denture three times daily for } 3 \text { years.) } \\
\text { The tests were performed in artificial saliva to lubricate the } \\
\text { double crowns during the wear process. } \\
\text { GROUP A } \\
\text { 1ry coping:- galvanoformed (gold) } \\
\text { 2ry coping:- non-noble (nickel } \\
\text { GROUP B } \\
\text { 1ry coping:- non-noble (nickel chromium) } \\
\text { 2ry coping:-galvanoformed (gold) } \\
\text { Before the wear test it is three times higher in } \\
\text { retention } \\
\text { After the wear test retention increased by } 134 \% \text {. }\end{array}$ & $\begin{array}{l}\text { conditions before and after } \\
\text { a wear test. }\end{array}$ \\
\hline Riera JJG et al. & $\begin{array}{l}\text {-Minimum milling height and taper would have to exceed } 4 \\
\text { mm with a 2-degree taper for long-term stability. } \\
\text {-The abutments (primary structures) and the Galvano- } \\
\text { copings (secondary structures) wereplaced on the master } \\
\text { cast and a 1-mm coat of wax was placed on the external } \\
\text { surface of the coping to provide a relief for cement. }\end{array}$ & $\begin{array}{l}\text { Alternative prosthetic } \\
\text { retentive means were } \\
\text { assessed. }\end{array}$ \\
\hline Bayer S et al. & $\begin{array}{l}\text { The double crowns were fabricated from high-gold-content } \\
\text { Type } 4 \text { alloys. } \\
\text { The crowns had a preparation of } 1-2^{\circ} \text {. A specifically } \\
\text { designed measuring device was used. The retentive forces } \\
\text { were measured with and without lubrication by a saliva } \\
\text { substitute. } \\
\text { The measured values were analyzed according to the type of } \\
\text { tooth (incisors, canines, premolars, and molars). } \\
\text { Thermoplastic material was filled into the primary } \\
\text { telescopic crowns to provide an adequateretention on the } \\
\text { inside of the crown. Spring-hard steel wires were provided } \\
\text { with retentionand fixed in position in the thermoplastic } \\
\text { material. The wires were manually aligned parallel to the } \\
\text { milling or withdrawal direction of the telescopic crown. The } \\
\text { surfaces of primary and secondary telescopic crowns were } \\
\text { cleaned with alcohol. The primary crowns were inserted } \\
\text { intothe secondary crowns using a ball plugger, which was } \\
\text { pressed onto the Kerr material. The retention force was then } \\
\text { measured by inserting the measuring stylus into the wire } \\
\text { retention and by withdrawing the telescopic crown axially. } \\
\text { Additionally, a comparison between lubricated and non- } \\
\text { lubricated telescopic crowns was done. }\end{array}$ & \\
\hline Stock V et al. & $\begin{array}{l}\text { Retentive Force was measured in a pull-off test ( } 20 \text { pull- } \\
\text { offs/specimen) }\end{array}$ & $\begin{array}{l}\text { To measure an in vitro } \\
\text { retention force of } \\
\text { doubleconical crowns } \\
\text { fabricated using different } \\
\text { materials primary and } \\
\text { secondary crowns with } \\
\text { different taper }(0,1 \text {, and } 2 \\
\text { degrees). }\end{array}$ \\
\hline Turp I et al. & $\begin{array}{l}\text { Samples were subjected to } 10,000 \text { insertion- } \\
\text { separationcycles in artificial saliva and retention force } \\
\text { wasmeasured. X-ray diffraction and scanning electron }\end{array}$ & $\begin{array}{l}\text { To evaluate zirconia as a } \\
\text { substitute for gold alloyin } \\
\text { primary crowns facing }\end{array}$ \\
\hline
\end{tabular}




\begin{tabular}{|c|c|c|}
\hline & microscopeanalysis were performed on the sample surfaces. & $\begin{array}{l}\text { secondary crowns } \\
\text { manufacturedwith } \\
\text { different materials, in } \\
\text { terms of long-term } \\
\text { retention force changes, } \\
\text { wear, and phase } \\
\text { transformation. }\end{array}$ \\
\hline Pietruski J K et al. & $\begin{array}{l}\text { Experiment of } 10.000 \text { in-and-out cycles was performed } \\
\text { using a new device which allows the retentive force to be } \\
\text { measured in continuous way without necessity of moving } \\
\text { the samples to another device. }\end{array}$ & $\begin{array}{l}\text { To measure an in vitro } \\
\text { retention force of double } \\
\text { conical crowns fabricated } \\
\text { using different materials } \\
\text { primary and secondary } \\
\text { crowns with different taper } \\
\left(2^{\circ}, 4^{\circ} \text { and } 6^{\circ}\right) \text {. }\end{array}$ \\
\hline
\end{tabular}

\begin{tabular}{|c|c|c|}
\hline Studies & Results & Histomorphometric Analysis \\
\hline $\begin{array}{l}\text { Grossman } \mathrm{AC} . \\
\text { Et al. }\end{array}$ & $\begin{array}{l}\text { The difference in OHIP before treatment and } 6 \text { and } 9 \\
\text { months later was significant (was better after treatment) } \\
\text { The author mentioned that treatment planning should be } \\
\text { based on objective factors including not only solid evidence } \\
\text { for clinical performance but also patient satisfaction and } \\
\text { OHRQoL. }\end{array}$ & $\begin{array}{l}\text {-Patients in the Galvanoformed } \\
\text { group } \\
\text { rated the retention }(P=.04) \text {. } \\
\text { - The difference between the } \\
\text { groups was } \\
\text { not significant at any time. With } \\
\text { the } \\
\text { exception of assessment of } \\
\text { overall denturefunction in the } \\
\text { Galvanoformed group,all other } \\
\text { ratings had a median of } \\
\text { 10,indicating a very high } \\
\text { satisfaction of } \\
\text { patients in both groups. }\end{array}$ \\
\hline Uludag B. et al. & $\begin{array}{l}\text { He mentioned that the electroformed crowns had a superior } \\
\text { fit in comparison to conventional cast crown. Also he } \\
\text { mentioned that the main advantage of zirconia copings lies } \\
\text { in the elimination of the galvanic currents and thermal } \\
\text { protection of the abutment teeth. However they are bulky } \\
\text { compared to the conventional casted copings. }\end{array}$ & N/A \\
\hline Besimo C et al. & $\begin{array}{l}\text { The mean initial retentive force of the pure titanium } \\
\text { telescopic crowns didn't differ statistically from the values } \\
\text { obtained from samples with secondary crowns cast in a } \\
\text { gold or a cr-co alloy. } \\
\text { Retention increased in the pure titanium and gold unlike cr- } \\
\text { co regardless of the angle. This is attributed to the } \\
\text { mechanical adaptation at the interface between the inner } \\
\text { and outer crowns. Such force characteristics might be the } \\
\text { result of different physical properties of the various } \\
\text { materials used (elastic modulus) } \\
\text { The delayed wear of the telescopic crowns might also have } \\
\text { been associated with the low force used to seat the outer } \\
\text { crown onto the inner crown }\end{array}$ & N/A \\
\hline Bayer $\mathrm{S}$ et al. & $\begin{array}{l}\text { The retention force measured intraorally is higher than the } \\
\text { extra oral values measured }\end{array}$ & $\begin{array}{l}\text {-The in vitro median value of } \\
1.97 \mathrm{~N} \text { to the in vivo median } \\
\text { value of } 4.70 \mathrm{~N} \text { by the } \\
\text { Mann-Whitney test showed a } \\
\text { significant }\end{array}$ \\
\hline
\end{tabular}




\begin{tabular}{|c|c|c|}
\hline & & $\begin{array}{l}\text { difference }(\mathrm{p}<0.0001) \text {. } \\
\text {-To compare the data of both } \\
\text { groups, a Spearman test was } \\
\text { performed. The result } \\
\text { of the test showed a Spearman's } \\
\mathrm{q}=0.5052 \text {. This means that the } \\
\text { values } \\
\text { are highly correlated with each } \\
\text { other. }\end{array}$ \\
\hline $\begin{array}{ll}\text { Singh K } & \& \\
\text { Gupta N } & \end{array}$ & $\begin{array}{l}\text { Tooth supported removable overdentures with telescopic } \\
\text { crowns provide better retention, stability,support,stable } \\
\text { occlusion, decrease in the forward sliding of the prosthesis } \\
\text { and better proprioceptive reflexes allowing better control of } \\
\text { mandibular movements which increase chewing efficiency } \\
\text { and phonetics. Also the rate of the residual ridge resorption } \\
\text { was decreased. }\end{array}$ & N/A \\
\hline $\begin{array}{l}\text { Kwon H B } \quad \& \\
\text { Lee SH }\end{array}$ & $\begin{array}{l}\text { The initial retentive force of double crown was affected by } \\
\text { the type of the double crown system. } \\
\text { Conus was better than the hybrid regarding the retention. }\end{array}$ & $\begin{array}{l}\text { The average retentive force in } \\
\text { group } \\
2 \text { (CONICAL), in which the } \\
\text { hybrid } \\
\text { outer crowns was used showed } \\
\text { higher } \\
\text { value than those of group } 1 \\
\text { (HYBRID) } \\
(p=.0198) \text {. }\end{array}$ \\
\hline $\begin{array}{l}\text { Jin Yi Y \& Park } \\
\text { C }\end{array}$ & $\begin{array}{l}\text { Insufficient or excessive retention in conical crown retained } \\
\text { denture is common. Gap between inner coping and outer } \\
\text { crown or removal difficulty, besides incomplete seating of } \\
\text { denture found in conical crown-retained denture were } \\
\text { assumed from the laboratory processing error occurred } \\
\text { during coping transfer procedure from the mouth to the } \\
\text { model. To prevent this problem, secure anchoring of inner } \\
\text { coping and re-examination and milling of convergence } \\
\text { angle was recommended on the master model from pick-up } \\
\text { impression. }\end{array}$ & N/A \\
\hline SAKAI Y et al. & $\begin{array}{l}\text {-Regarding the effect of tapered angle on retentive force, } \\
\text { the smaller the tapered angle of the cone crowns the greater } \\
\text { the retentive force was. } \\
\text {-The retentive force in the cone crown telescopic system is } \\
\text { considered to be generated mainly by the residual elastic } \\
\text { strain in the outer crown. This elastic strain occurs due to } \\
\text { the deformation of the outer crown on the inner crown } \\
\text { when occlusal force is applied firmly, and remains when the } \\
\text { occlusal force is separated because of the existence of the } \\
\text { inner crown. } \\
\text {-The retentive force of the cone crown telescopic system is } \\
\text { produced by not only residual elastic strain due to friction } \\
\text { but also other factors such as the micro interlocking effect } \\
\text { especially when it is metal to metal. } \\
\text {-The wear resistance of gold alloy was } 3.4 \text { times greater } \\
\text { than that of pure titanium, therefore the wear resistance of } \\
\text { (titanium alloy with } 6 \% \text { aluminum and } 7 \% \text { niobium is) not } \\
\text { better than that of gold alloy. } \\
\text {-The experimental cone crown telescopic system was } \\
\text { designed for dental implants. The greater retentive force of } \\
\text { the cone crown telescopic system has been suggested to }\end{array}$ & $\begin{array}{l}\text { The effects of tapered angle on } \\
\text { retentive } \\
\text { Forces were analyzed by nested } \\
\text { 2-way ANOVA, selecting } \\
\text { combinations } \\
\text { of tapered angle and number of } \\
\text { cycles } \\
\text { of insertion and separation, and } \\
\text { Tukey's } \\
\text { HSD test using statistical } \\
\text { software. } \\
\text { The significance level was set at } \\
0.05 \text {. }\end{array}$ \\
\hline
\end{tabular}




\begin{tabular}{|c|c|c|}
\hline & $\begin{array}{l}\text { bind implant to the abutments tightly; consequently, a } \\
\text { secondary splinting effect could benefit the Osseo- } \\
\text { integration of immediately loaded implants. }\end{array}$ & \\
\hline Mansour S et al. & $\begin{array}{l}\text { It was demonstrated that there are applications of zirconia } \\
\text { in implants dentistry while cementing of telescopic crowns } \\
\text { to implants' abutments which is controversial to the one- } \\
\text { piece milled telescopic abutments as an alternatives and } \\
\text { economically treatment option. Longitudinal studies have to } \\
\text { prove the success of this method. }\end{array}$ & N/A \\
\hline $\begin{array}{l}\text { Gurbulak AG et } \\
\text { al. }\end{array}$ & $\begin{array}{l}\text { - The retention force of a telescopic crown is influenced by } \\
\text { factors of abutment tooth preparation, such as taper angle, } \\
\text { height, and marginal design, and also by factors associated } \\
\text { with the fabrication process, such as milling speed, degree } \\
\text { of cutter wear, polishing, casting technique, and setting } \\
\text { method also the contact surface pressure,surface roughness } \\
\text { and the static frictional coefficient (SFC) have a great } \\
\text { influence on the retention thus it could be controlled by } \\
\text { changing the taper angle of the double crown and the } \\
\text { thickness of the secondary crown. } \\
\text { The reasons that group B is higher in retention after the } \\
\text { wear test than group A is:- } \\
\text { 1-Galvanoformed crowns fit precisely to dental restorations } \\
\text { and also improve marginal fitting due to the elastic } \\
\text { deformation. } \\
\text { 2- Contact surface pressure and cone angle did not vary, but } \\
\text { the difference in crown materials caused a variation in SFC. } \\
\text { Retentiveforces in conical double crowns are generated by } \\
\text { the residual elastic strain in the secondary crown, which } \\
\text { correlates with the SFC. } \\
\text { 3-Change in weight after the wear test. } \\
\text { 4-Smooth surface of } 2 \text { ry coping (after the wear test) in } \\
\text { group B increased contact unlike internal beads in group A. } \\
\text { 5-Plastic deformation occurring increased the actual contact } \\
\text { area. } \\
\text { As a conclusion secondary coping is more influential in the } \\
\text { retention beside the advantages of the galvanoforming } \\
\text { technique weremanifested in the secondary crown but not in } \\
\text { the primary crown. }\end{array}$ & $\begin{array}{l}\text { In group A, the wear test had a } \\
\text { significant influence on the } \\
\text { retentive } \\
\text { force }(p \quad<0.05) \text {, but wear } \\
\text { produced no } \\
\text { significant difference in weight } \\
(p>0.05) \text {. In group } \\
\mathrm{B} \text {, the wear test had a significant } \\
\text { influence on the retentive force } \\
(p<0.05) \text {, and wear } \\
\text { produced a significant difference } \\
\text { in } \\
\text { weight }(p<0.05) \text {. }\end{array}$ \\
\hline Riera JJG et al. & $\begin{array}{l}\text {-Prosthetic restoration of the edentulous maxilla with } \\
\text { osseointegrated implants and a telescopic detachable } \\
\text { prosthesis using Galvanic copings was presented as an } \\
\text { alternative to traditional retention techniques for } \\
\text { overdentures. } \\
\text {-The use of basic parallel-milling techniques and electro- } \\
\text { forming permitted the fabrication of a prosthesis with } \\
\text { significant retention and few moving parts, further } \\
\text { minimizing potential maintenance. }\end{array}$ & N/A \\
\hline Bayer S et al. & $\begin{array}{l}\text {-No statistically significant difference between lubricated } \\
\text { and unlubricated specimens was found. } \\
\text {-The results indicate that retention force values of } \\
\text { telescopic crowns, measured in clinical practice, are often } \\
\text { much lower than those cited in the literature. } \\
\text {-The measurements also show a wide range. Whether this } \\
\text { proves to be a problem for the patient's quality of life or not } \\
\text { can however only be established by a comparison of the } \\
\text { presented results with a follow-up study involving }\end{array}$ & $\begin{array}{l}\text {-The median retention force } \\
\text { value was calculated for each } \\
\text { telescopic crown and } \\
\text { differentiated according tothe } \\
\text { type of tooth showed that the } \\
\text { measurements do not differ } \\
\text { significantly (Kruskal-Wallis } \\
\text { test,p=0.6334). } \\
\text {-The statistical analysis was }\end{array}$ \\
\hline
\end{tabular}




\begin{tabular}{|c|c|c|}
\hline & $\begin{array}{l}\text { measurement of intraoral retention and determination by } \\
\text { e.g. oral health impact profile }\end{array}$ & $\begin{array}{l}\text { performedby a Mann-Whitney } \\
\text { test. } \\
\text { It showed that there was } \\
\text { nosignificant difference between } \\
\text { the measurements with and } \\
\text { without saliva lubrication } \\
(\mathrm{p}=0.0506) \text {. }\end{array}$ \\
\hline Stock V et al. & $\begin{array}{l}\mathrm{CoCr} \text { and } \mathrm{ZrO} 2 \text { mainly adhere through friction and } \\
\text { wedging, whereas galvanic crowns basically adhere by } \\
\text { hydraulic adhesion. It can be assumed that the variation in } \\
\text { the results is not only material related, but also especially } \\
\text { related to the manufacturing techniques. } \\
\text { The viscosity of the applied saliva, as well as the chamfer } \\
\text { design, may influence the hydraulic adhesion and, thus, the } \\
\text { retention force as well. }\end{array}$ & $\begin{array}{l}\text { Cobalt Chromium } \mathrm{CoCr} \text { and } \\
\text { Zirconium dioxide } \mathrm{ZrO} 2 \text { both } \\
\text { present a high elastic modulus } \\
(200 \mathrm{GPa}) \text { and are rigid and } \\
\text { stable ( } 280 \mathrm{HV} 10 ; 1200 \mathrm{HV} 10) \\
\text {. PEEK, in contrast, is soft and } \\
\text { ductile ( } 110 \mathrm{HV} 5 / 20) \text { and shows } \\
\text { a low elastic modulus ( } 4 \mathrm{GPa}) \text {. } \\
\text { Putting a CoCr or } \mathrm{ZrO} 2 \\
\text { secondary crown on a PEEK } \\
\text { primary crown could lead to a } \\
\text { strong wedging due to the } \\
\text { flexibility of PEEK and the } \\
\text { differences in elastic modulus. } \\
\text { This could be a possible } \\
\text { explanation as to why } 2 \text { degree } \\
\text { tapered crowns show higher } \\
\text { retention force values than } 0 \\
\text { degree tapered crowns. }\end{array}$ \\
\hline Turp I et al. & $\begin{array}{l}\text { A more predictable and less excursive retentionforce can be } \\
\text { obtained using a hard and rigid primary crownmaterial like } \\
\text { zirconia. }\end{array}$ & $\begin{array}{l}\text { Zirconia }(1,250 \mathrm{HV}) \text { is a harder } \\
\text { material than the gold alloy ( } 295 \\
\mathrm{HV}) \text {, theadaptation of the double } \\
\text { crown takes place with the } \\
\text { deformationof the secondary } \\
\text { crown to fit the primary crown, } \\
\text { without anywear on the primary } \\
\text { crown. Therefore, the use of a } \\
\text { hard andwear-resistant primary } \\
\text { crown material against a less } \\
\text { hard secondarycrown } \\
\text { materialmay be advantageous. }\end{array}$ \\
\hline $\begin{array}{l}\text { Pietruski J K et } \\
\text { al. }\end{array}$ & $\begin{array}{l}\text { It appears that the strength of this correlation is determined } \\
\text { by the type of the material pair and also the coping } \\
\text { fabrication technique. }\end{array}$ & $\begin{array}{l}\text { Dispersion of retention values is } \\
\text { similar in material combination } \\
\text { casting alloy/electroforming as } \\
\text { comparedto casting alloy/casting } \\
\text { alloy, but when cone angle was } \\
2^{\circ} \text { or } 4^{\circ} \text {, stability of retention } \\
\text { force with the passage of time } \\
\text { was higher in combinations with } \\
\text { electroformed copings. }\end{array}$ \\
\hline
\end{tabular}

\section{Discussion:-}

The cardinal aim of the review is to investigate how strong the value of retentive force of telescopic crowns in an implant-supported overdenture is in clinical practice. 
In the field of the double crown technique, studies regarding PEEK on implants are scarce. Telescopic crowns on implants are effective in prosthesis stabilization with regard to horizontal forces in cases of advanced atrophy of the alveolar crest ${ }^{[4,19]}$.

It was revealed that the variation in the results is not only material related, but also related to the manufacturing techniques $^{[4]}$.

(PEEK) showed higher values of retention compared to (metal). In cases where the primary crown is made of metal and the secondary crown is made of PEEK and it was proven that the secondary crown is the determinant of the retentive forces ${ }^{[15]}$. Whereas the hardness of 1ry crown (metal) $(455.88 \mathrm{HV}$ ) is more than that of the 2ry crown (PEEK) $(110 \mathrm{HV})$, therefore, the use of a hard and wear-resistant primary crown material against a less hard secondary crown material is advantageous. Thus, the adaptation between primary and secondary crowns will be achieved by the changes in the fitting surface of the secondary crown ${ }^{[4,5]}$.

Another potential explanation is that PEEK is a soft and ductile material that yields and adapts well. The adaption process resulted in a good marginal fit.

Persistence of retentive forces in conical crowns with the passage of time is higher in combinations of materials between the primary and secondary crowns ${ }^{[18]}$.

It was also claimed that the casting methods caused the formation of very minute microscopic casting beads on the internal and external surfaces of the primary and secondary crowns. Unfortunately, it is technically impossible to remove these casting beads from the surfaces of the cast crowns which apparently affect the retention by time ${ }^{[15]}$.

\section{Conclusion:-}

Implant retained mandibular overdenture with telescopicattachments is a successful treatment option regarding the retention and improved overall function.

The retention force of a telescopic crown is influenced by factors of abutment preparation, such as taper angle, height, and marginal design, and also by factors associated with the fabrication process, such as milling speed, degree of cutter wear, polishing, casting technique, and setting method also the contact surface pressure ,surface roughness in addition to the static frictional coefficient (SFC) have a great influence on the retention thus it could be controlled by changing the taper angle of the double crown and the thickness of the secondary crown.

The use of a harder and more wear-resistant primary crown material against a less hard secondary crown material is advantageous because the adaptation between primary and secondary crowns is increased by the changes in the fitting surface of the secondary crown. Unfortunately this conclusion is based on a limited number of articles, indicating the need for more clinically controlled randomized studies.

\section{References:-}

1. LaBarre E, Giusti L and Pitigoi-Aron G, Addressing problems in complete dentures. Compend Contin Educ Dent, 2007. 28: p. 538-542.

2. Frisch E, Ziebolz D, Ratka KP and Rinke S, Double Crown Retained Maxillary Overdentures: 5 Year Follow Up. Clin Implant Dent Relat Res, 2015. 17: p. 22-31.

3. Meijer HJ, Raghoebar GM, Van't Hof MA, Geertman ME and Van Oort RP, Implant-retained mandibular overdentures compared with complete dentures; a 5-years' follow-up study of clinical aspects and patient satisfaction. Clin Oral Implants Res, 1999. 10: p. 238-244.

4. Stock V, Schmidlin PR, Merk S, Wagner C, Roos M, Eichberger M and Stawarczyk B, PEEK Primary Crowns with Cobalt-Chromium, Zirconia and Galvanic Secondary Crowns with Different Tapers-A Comparison of Retention Forces. Materials J, 2016. 9: p. 187-188.

5. Turp I, Bozdağ E, Sünbüloğlu E, Kahruman C, Yusufoğlu İ and Bayraktar G, Retention and surface changes of zirconia primary crowns with secondary crowns of different materials. Clin Oral Investig, 2014. 18: p. 20232035.

6. Grossmann AC, Hassel AJ, Schilling O, Lehmann F, Koob A and Rammelsberg P, Treatment with double crown-retained removable partial dentures and oral health-related quality of life in middle- and high-aged patients. Int J Prosthodont, 2007. 20(6): p. 576-8. 
7. Uludag B, Sahin $\mathrm{V}$ and Ozturk $\mathrm{O}$, Fabrication of zirconium primary copings to provide retention for a mandibular telescopic overdenture: a clinical report. Int J Prosthodont, 2008. 21: p. 509-510.

8. Besimo $\mathrm{CH}$, Graber $\mathrm{G}$ and Fluhler M, Retention force changes in implant-supported titanium telescope crowns over long-term use in vitro. J Oral Rehabil, 1996. 23: p. 372-378.

9. Bayer S, Stark H, Golz L, Keilig L, Kraus D, Hansen A and Enkling N, Telescopic crowns: extra-oral and intraoral retention force measurement--in vitro/in vivo correlation. Gerodontology, 2012. 29: p. 340-347.

10. Singh K and Gupta N, Telescopic denture - a treatment modality for minimizing the conventional removable complete denture problems: a case report. J Clin Diagn Res, 2012. 6: p. 1112-1116.

11. Kwon HB, Roh YH and Lee SH, The comparison of initial retentive force in different double crown systems. J Korean Acad Prosthodont, 2006. 44: p. 677-682.

12. Yi YJ, Cho LR and Park CJ, Cause of technical failures of conical crown-retained denture (CCRD): a clinical report. J Korean Acad Prosthodont, 2003. 41: p. 714-719.

13. Sakai $\mathrm{Y}$, Takahashi H, Iwasaki N and Igarashi $\mathrm{Y}$, Effects of surface roughness and tapered angle of cone crown telescopic system on retentive force. Dent Mater J, 2011. 30: p. 635-641.

14. Mansour S, Setz JM and Boeckler ODAF, All-ceramic one-piece telescopic abutments for implant-supported overdentures. Int Poster J Dent Oral Med, 2016. 3: p. 540 - 554.

15. Gurbulak AG, Kilic K, Eroğlu Z, Gercekcioglu E and Kesim B, Evaluation of the retention force of double conical crowns used in combination with a galvanoforming and casting fabrication technique. J Prosthodont, 2013. 22: p. 63-68.

16. Gutierrez Riera JJF, Albano R.; Rivera, Francisco Zárate; Salinas, Thomas J., Alternative Designs in ImplantRetained Maxillary Overdentures: The Telescopic Approach. Quint Dent Tech, 2006. 29: p. 127-129.

17. Bayer S, Stark H, Mues S, Keilig L, Schrader A and Enkling N, Retention force measurement of telescopic crowns. Clin Oral Investig, 2010. 14: p. 607-11.

18. Pietruski JK, Sajewicz E, Sudnik J and Pietruska MD, Retention force assessment in conical crowns in different material combinations. Acta of Bioeng and Biomech, 2013. 15: p. 35-42.

19. Verma R, Joda T, Brägger U and Wittneben JG, A Systematic Review of the Clinical Performance of Tooth-Retained and Implant-Retained Double Crown Prostheses with a Follow-Up of $\geq 3$ Years. J Prosthodont, 2013. 22: p. 2-12. 